\title{
Membangun Mental Positif Buruh Perempuan Korban PHK Pandemi Covid 19 di Kawasan Industri Pulogadung, Jakarta Timur
}

\author{
Building a Positive Mentality for Female Workers Victims of Layoffs in the Covid-19 Pandemic \\ in the Pulogadung Industrial Estate, East Jakarta
}

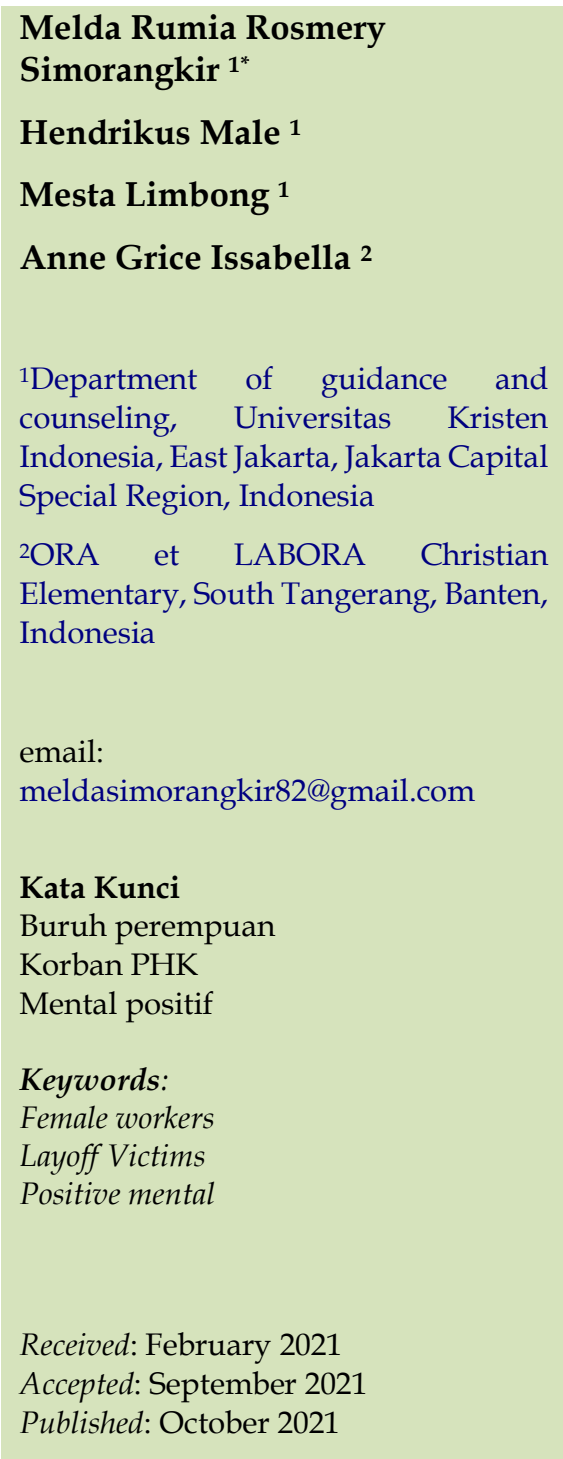

\begin{abstract}
Abstrak
Kondisi pandemi COVID-19 dialami oleh berbagai lapisan masyarakat, pengaruhnya sangat besar diberbagai sektor. Sementara selama masa pandemi di berlakukan karantian untuk memutus mata rantai COVID-19 seluruh masyarakat harus melakukan kegiatan bekerja, ibadah, dan belajar dari rumah. Selama proses karantina mereka kebingungan untuk melakukan kegiatan, sehingga tidak jarang berkonflik baik dengan diri sendiri maupun dengan orang diluar dirinya sehingga mental yang positif harus dibangun untuk dapat memotivasi diri sendiri. Metode yang digunakan dalam pengabdian kepada masyarakat ini adalah dengan konseling individu, konseling dilakukan pada buruh perempuan korban pemutusan hubungan kerja dikawasan industri Pulogadung Jakarta Timur. Melalui kegiatan pengabdian kepada masyarakat buruh perempuan korban pemutusan hubungan kerja, menjadi belajar bagaimana mereka memotivasi diri sendiri dengan melihat potensi diri dan melihat sisi baik dari setiap kejadian. Para buruh juga saling menolong dan mengarahkan orang lain dan diri sendiri selalu berfikir positif dan siap bangkit hadapi kondisi pandemi dengan mental yang sehat.
\end{abstract}

\begin{abstract}
Various levels of society experience the condition of the COVID-19 pandemic; its influence is enormous in multiple sectors. Meanwhile, during the pandemic period, a quarantine is imposed to break the chain of COVID-19. The entire community must carry out work, worship, and study activities from home. During the quarantine process, they are confused about what to do, so they often conflict with themselves and with people outside themselves. So that a positive mentality must be built to be able to motivate yourself. The method used in this community service is individual counseling; counseling is carried out on female workers who are victims of layoffs in the Pulogadung industrial area, East Jakarta. Through community service activities, female workers who are victims of layoffs learn how to motivate themselves by seeing their potential and the good side of every incident. The workers also help each other and direct others to always think positively and be ready to rise to face the pandemic conditions with a healthy mentality.
\end{abstract}

(c) 2021 Melda Rumia Rosmery Simorangkir, Hendrikus Male, Mesta Limbong, Anne Grice Issabella. Published by Institute for Research and Community Services Universitas Muhammadiyah Palangkaraya. This is Open Access article under the CC-BY-SA License (http://creativecommons.org/licenses/by-sa/4.0/). DOI: https://doi.org/10.33084/pengabdianmu.v6i6.2094

\section{PENDAHULUAN}

Virus Corona atau severe acute respiratory syndrome coronavirus 2 (SARS-CoV-2) adalah virus yang menyerang sistem pernapasan. Penyakit karena infeksi virus ini disebut COVID-19. Virus Corona bisa menyebabkan gangguan ringan pada sistem pernapasan, infeksi paru-paru yang berat, hingga kematian (Timah, 2021). SARS-CoV-2 yang lebih dikenal dengan nama virus Corona adalah jenis baru dari corona virus yang menular ke manusia. Virus ini sendiri bisa 
menyerang siapa saja, tidak perduli laki-laki atau perempuan, bayi atau lansia, kaya atau miskin tidak menjadi alasan bahwa individu tersebut kebal terhadap virus mematikan ini (Sa'diyah \& Amiruddin, 2020). Begitu besar dampak yang dirasakan oleh dunia secara khusus bangsa Indonesia akibat Covid-19 berbagai sektor menjadi lumpuh, baik sektor pendidikan, kesehatan ekonomi, bahkan ketenagakerjaan.

Setiati dan Azwar (2020) dalam penelitiannya mengungkapkan bahwa pandemi infeksi virus corona 2019 (Covid-19) bukan hanya dihadapi di Indonesia atau ASIA, ini adalah masalah yang sedang dihadapi di lebih dari 200 negara di dunia. Indonesia juga terkena dampak buruk dari COVID-19, hingga akhir Maret 2020 tingkat kematiannya mencapai $8.9 \%$. Pada 16 Maret 2020 pemerintah mengambil kebijakan besar dalam rangka memutus mata rantai virus Corona yaitu dengan mengambil langkah PSBB (Pembatasan Sosial Bersekala Besar) sehingga melakukan kegiatan belajar, bekerja dan ibadah dirumah, dianjurkan bagi Indonesia untuk memperketat himbauan untuk diam di rumah, menurunkan penyebaran penyakit dengan karantina wilayah dalam skala besar, meningkatkan pelayanan kesehatan, serta meningkatkan ketersediaan alat pelindung diri (APD) (Pujaningsih \& Sucitawathi, 2020). Seperti dilaporkan oleh Romlah (2020), Menteri Ketenagakerjaan Republik Indonesia Ida Fauziyah di Jakarta, Rabu (08/04/2020) mengatakan, pada 7 April 2020 setidaknya terdapat 39.977 perusahaan yang terdampak atas pandemi Corona virus ini dan setidaknya terdapat 137.489 buruh yang telah di PHK.

Melalui kompas.com pada 23 April 2020 Menteri Pemberdayaan Perempuan dan Perlindungan Anak (PPPA) I Gusti Ayu Bintang Darmawati mengungkapkan besarnya dampak pandemi Covid 19 pada sektor sosial dan ekonomi membuat pekerja perempuan harus menerima dampak Pemutusan
Hubungan Kerja (PHK). Data yang diambil 16 April 2020 jumlah pekerja yang terkena dampak PHK sebanyak 2.358 orang, 30\% diantaranya yaitu sebanyak 762 orang pekerja perempuan. Sementara sejak Maret 2020 sebanyak 32.000 pekerja migran pulang ke Tanah Air dan $70 \%$ diantaranya adalah pekerja migran perempuan. Perempuan baik yang sudah berkeluarga maupun perempuan yang belum berkeluarga memiliki alasan berbeda-beda sehingga mereka memutuskan untuk bekerja. Berbagai alasan perempuan ikut bekerja termasuk menjadi buruh, diantara bekerja sebagai aktualisasi diri, pemenuhan kebutuhan pribadi, agar ada kegiatan yang terarah, atau bahkan untuk membantu peranan suami dalam pemenuhan kebutuhan keluarga. Kedewasaan secara psikis sangat diperlukan bagi perempuan yang sudah menikah untuk mampu berperan dengan baik, sebagai ibu rumah tangga, istri, ibu bagi anak-anak, dan karyawan di tempat bekerja (Wakirin, 2017).

Ismawati (2019) melaporkan bahwa perempuan berperan sangat luat saat ini, tidak lagi hanya mengurus, merawat dan melayani anak serta suami dirumah, menjadi ibu berkerja untuk mencukupi kebutuhan keluarga demi suami dan anak juga harus dilakukan untuk kesejahtraan keluarga. Melalui peneitian tersebut prempuan juga ternyata harus terampil baik dirumah maupun diluar rumah untuk dapat membantu suami memenuhi segala kebutuhan dalam sebuah keluarga. Terbatasnya latar belakang pendidikan menjadi salah satu alasan perempuan harus bekerja menjadi buruh baik urban maupun migran. Wijayanti (2010) melaporkan bahwa Perempuan buruh pada umumnya memiliki tingkat pendidikan rendah, bekerja disektor pekerjaan yang tidak memerlukan pendidikan tinggi, ketrampilan dan keahlian khusus, serta berupah rendah. Salah satu pekerjaan yang dilakukan perempuan adalah sebagai buruh pabrik. Hasil penelitian tersebut tentu di 
perkuat oleh tim PKM UKI yang menjadikan korban buruh pabrik garmen di Cakung Jakarta Timur menjadi bagian yang perlu diperhatikan secara psikis.

Kondisi pandemi yang membuat banyak perempuan ter-PHK tentu sangat berpengaruh secara psikologis bagi mereka dan bagi keluarga. Kesulitan ekonomi pasti menjadi dampak terbesar dalam keluarga, perempuan menjadi lebih sensitif, mudah marah, anak-anak menjadi korban kemarahan, malakukan pinjaman uang baik kepada bank resmi maupun rentenir, konflik dengan suami atau bahkan dengan lingkungan sekitar. Dalam rangka meringankan beban perekonomian, pemerintah menyiapkan bantuan berupa sembako dan bantuan langsung tunai (BLT) sebesar Rp. 600.000,00 untuk meringankan kebutuhan dalam keluarga. Pramanik (2020) dalam penelitian yang dilakukan di Bandung, Jawa Barat didapati hasil bahwa bantuan paket sembako dan bantuan langsung tunai sangat berpengaruh, diharapkan pembagian sembako dan BLT dapat dilakukan secara merata tepat. Kondisi pemberhentian bekerja selama pandemi Covid 19 yang sangat berpengaruh pada perekonomian perempuan dan keluarganya sedikit terbantu dengan bantuan pemerintah. Disadari BLT dan sembako yang diberikan pemerintah sangat membantu warga, tapi bagian lain tetap harus dilakukan seperti pembayaran listrik, kuota internet anak, SPP sekolah anak, kontrakan, uang jajan anak, dan kebutuhan lain di luar sembako. Pasalnya kebutuhan-kebutuhan tersebut harus terpenuhi dan harus segera dibayarkan, kebutuhan-kebutuhan tersebut sama pentingnya dengan kebutuhan sembako yang merupakan bahan pokok kehidupan sehari-hari.

Selain dampak perekonomian yang sulit akibat PHK dampak lain yang dialami adalah gangguan psikologis yang bisa berdampak pada kepercayaan diri, karena manusia tentu akan relatif tidak bahagia bila ternyata tidak lagi bekerja. Dalam penelitian yang dilakukan kepada kepala keluarga, Sari (2015) mengungkapkan pemutusan hubungan kerja pada kepala keluarga dapat menimbulkan perasaan kecewa, bingung, dan sedih. Perasaan tersebut tentu bukan hanya dirasakan oleh kepala keluarga, namun juga berdampak kepada istri dan seluruh anggota keluarga.

Dosen-dosen UKI bersama dengan Kepala sekolah SDK Ora Et Labora Pamulang Tangerang- Banten, bersamasama bersinergi untuk menolong para perempuan yang sudah berkeluarga untuk membangun mental positif mereka selama menghadapi pandemi Covid 19 yang berdapak pada pekerjaan mereka. Perempuan sangat rentan terhadap kekerasan dalam rumah tangga, kondisi karantina yang dilakukan serentak diseluruh Indonesia tentu membuat perempuan harus ektstra sabar menghadapi suami, anak-anak, dan keluarga yang semuanya melakukan kegiatan dirumah. Dalam penelitiannya, Fazraningtyas et al. (2020) menjelaskan melalui data yang diterbitkan oleh WHO (2018) menunjukkan bahwa sekitar 1 dari 3 (35\%) perempuan di seluruh dunia telah mengalami kekerasan. Selama masa pandemi COVID-19yang terjadi hampir di seluruh belahan dunia kekerasan dalam rumah tangga justru membuat angkanya semakin meningkat. Pembatasan sosial yang dilakukan selama masa pandemi sangat berdampak besar pada perekonomian, ekonomi keluarga terpuruk, dan berimbas pada situasi dan kondisi perempuan. Segala kegiatan yang terpusat di rumah membuat beban domestik yang sangat besar bagi perempuan, mulai dari mengurus rumah hingga memastikan anak-anak mengakses pendidikan dari rumah.

Penguatan psikologis sangat dibutuhkan bagi perempuan, untuk meyakinkan bahwa mereka mampu menghadapi kesulitan dengan tenang, bijak serta tidak merasa sendiri, para pekerja perempuan harus di yakinkan bahwa kondisi PHK selama pandemi Covid 19 
dapat berlalu dengan baik selama dijalankan dengan selalu berfikir positif. Naan dan Nurlaela (2020) mengungkapkan bahwa dalam penanganan kasus covid-19 tidak hanya ditangani dengan cara medis, tapi juga dilengkapi pemanfaatan kekuatan pikiran positif berlandaskan pada Tuhan. Jiwa akan sehat apabila pikiran dilatih konsentrasi, pernafasan yang tepat dan sikap yang benar dalam menghadapi wabah corona. Perempuan korban PHK selama pandemi Covid 19 juga harus ditolong dalam membangun mental yang positif, satu orang yang tertolong tentu ini akan menolong yang lain untuk berfikir positif terhadap kondisi yang mereka hadapi.

\section{METODOLOGI}

Dalam kegiatan pengabdian masyarakat yang dilakukan oleh beberapa dosen dan guru adapun bahan yang digunakan dalam kegiatan ini adalah dengan memberikan video-video penguatan kepada perempuan korban PHK, video berisi tentang kondisi dunia yang sedang mengalami pandemi Covid 19. Para buruh mulai menyadari bahwa bukan hanya mereka yang mengalami keterhimpitan ekonmoi namun ada jutaan perempuan yang juga mengalami hal yang sama. Metode yang digunakan dalam kegiatan ini adalah dengan melakukan konseling individu. Konseling individu adalah salah satu pendekatan yang diguanakn untuk membantu masalah yang dihadapi individu.

Kegiatan diawali dengan meminta ijin melalui Ketua Federasi Serikat Buruh Indonesia (FSBI) tentang pelaksanaan PKM yang akan diberikan kepada buruh perempuan korban PHK. Setelah itu tim PKM melakukan observasi, setelah observasi dilakukan kegiatan membangun mental postif dilakukan di kantin pabrik garmen di kawasan industri Pulogadung dan juga melalui daring. Evaluasi juga dilakukan untuk melihat perkembangan para buruh setelah melakukan konseling individu.

\section{HASIL DAN PEMBAHASAN}

Melalui kegiatan PKM ini para buruh diberikan kesempatan untuk menceritakan perasaan mereka ketika mendapatkan informasi terkait pemberhentian yang mereka dapatkan. Selain itu para buruh tersebut bisa menceritakan apa saja perasaan mereka dengan leluasa, beberapa dari mereka menangis karena merasa kehidupan semakin sulit, beberapa dari mereka adalah orangtua tuanggal yang harus menghidupi anak-anak, kontrakan, dan berbagai kebutuhan dalam keluarga. Para buruh umumnya adalah para buruh urban, mereka datang ke Jakarta hanya untuk bekerja, pindah ke kampung halaman menurut mereka tentu akan menambah beban baru untuk keluarga. Apalagi mengingat bila mereka pindah harus memikirkan kepindahan anak sekolah, barang-barang yang mereka miliki dan dampaknya bagi keluarga dikampung halaman.

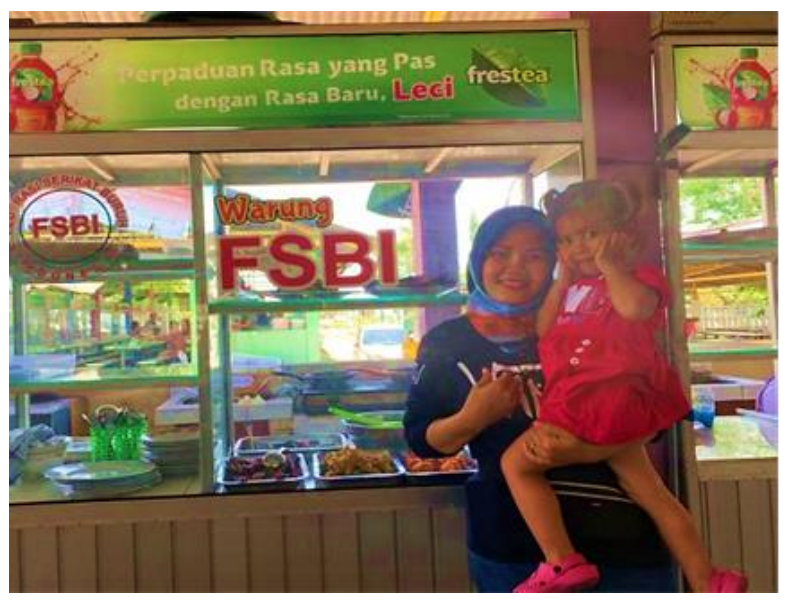

Gambar 1. Buruh Perempuan korban PHK

Melalui kegiatan konseling individu yang dilakukan pada buruh perempuan korban PHK diharapkan para buruh bisa bangkit dari masa keterpurukan, memikirkan bersama dan melahirkan ide-ide baru kegiatan yang dapat dilakukan untuk dapat bertahan menghadapi 
masa pandemi Covid 19. Melalui pendampingan dan kegiatan konseling para buruh perempuan bersama dengan rekan-rekan yang senasib mencoba membuat warung makan sederhana dikantin kawasan industri Pulogadung. Kantin dikawasan tersebut berada di tengah-tengah kawasan industri, disekitar kantin terdapat 8 pabrik garmen.

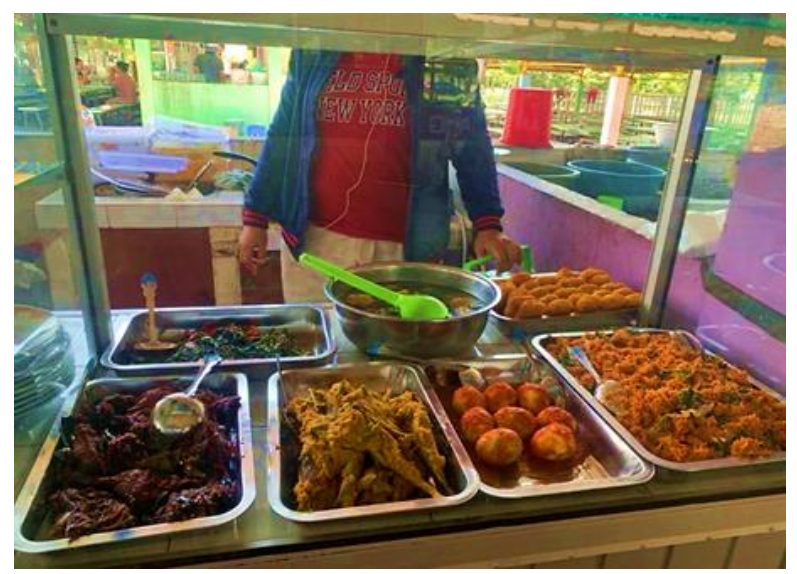

Gambar 2. Jenis makanan yang dijual Perempuan Korban PHK

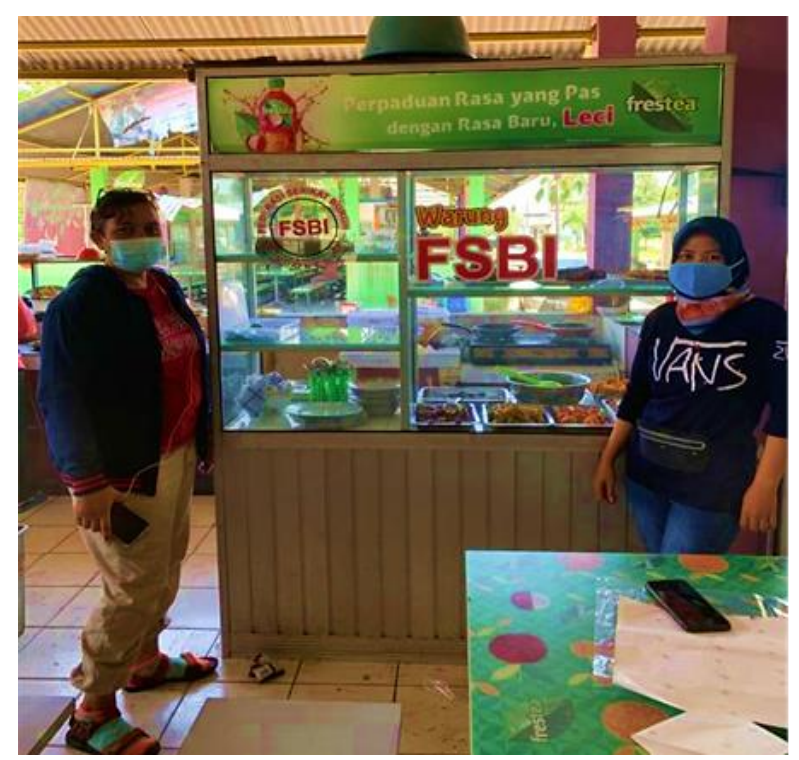

Gambar 3. Tugas diberikan sesuai keahlian

Para buruh perempuan ini tidak semua memiliki kesempatan yang sama untuk bisa bangkit dan mengadapi kondisi dengan positif. Setelah beberapa buruh tertolong secara psikologis diharap mereka juga mampu menolong teman mereka. Para buruh tersebut dikembangkan potensi dalam diri mereka, mereka melakukan kegiatan sesuai dengan kemampuan mereka. Pembagian tugas mulai belanja, memasak, mencuci piring, menjaga anak-anak ketika ibu bekerja, dan membersihkan kantin dilakukan secara bersamasama.

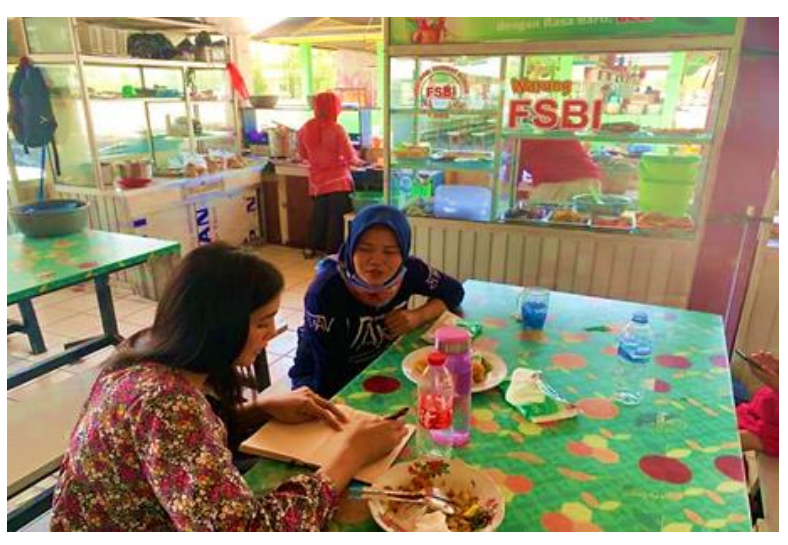

Gambar 4. Kegiatan Konseling Individu

Kegiatan konseling sangat menolong para perempuan korban PHK, mereka tidak lagi merasa sendiri dan tidak memiliki harapan. Berdasarkan hasil wawancara yang lakukan setelah proses konseling individu, Ulfa mengungkapkan "Saya senang bapak ibu bersedia datang melihat kami, saya cuma sekolah sampai SMP jadi tidak paham tentang bagaimana membuat mental itu harus tetap positif". Beberapa diantara mereka juga mengungkapkan mereka senang, bahwa ternyata pandangan mereka tentang dosen yang hanya duduk di universitas bisa datang untuk bersama-sama duduk untuk membantu mereka, menjadi sahabat mereka kala kondisi saat ini.

Kegiatan ini berlangsung sejak September sampai Oktober 2020. Awalnya harga makanan yang mereka buat terlalu tinggi, namun menyadari kondisi perekonomian yang tidak stabil, para buruh sepakat untuk memberikan patokan harga per porsi mulai Rp.10.000 - Rp.13.000 harga tersebut dianggap sangat murah. Dalam proses konseling para buruh juga diharapkan tetap memberikan makanan dengan gizi yang baik dan bersih, selain itu setelah proses konseling 
para buruh juga memberikan kesempatan bagi buruh perempuan yang lain untuk menitipkan makanan atau jualan mereka di warung nasi yang mereka miliki.

Masalah ekonomi keluarga saat ini mereka bisa tangani walau sangat perlahan, setidaknya para buruh menyadari kini mereka memiliki kegiatan yang bermanfaat. Mereka tetap bisa bekerja dan menjaga mengawasi anak-anak. Beberapa dari mereka juga mulai bersyukur dengan kondisi pandemi Covid 19. Mereka bersyukur sehingga mereka bisa setiap hari bertemu anak-anak sehingga anak-anak menjadi begitu dekat dengan ibunya, bahkan ketika mereka berjualan anakanak tetap bisa diawasi, karena pasalnya kantin buka pada pukul 9.00-13.30 WIB. kantin dibuka pada jam tersebut karena jam istirahat buruh yang berlangsung sejak pukul 11.30 - 13.00 WIB.

\section{KESIMPULAN}

Melalui kegiatan PKM di kawasan industri Pulogadung, para buruh merasa sangat senang dengan kegiatan konseling individu dalam rangka membangun mental postif. Para buruh kini menyadari bahwa mereka masing-masing memiliki potensi diri yang begitu besar untuk di kembangkan utnuk menghadapi kesulitan ekonomi di masa pandemi setelah masa PHK. Mereka belajar untuk sabar ketika harus mengajar anak dirumah dengan berbagai metode baru yang belum pernah mereka lihat atau sentuh, mereka belajar menjadi pendengar yang baik untuk pasangan mereka dan teman-teman yang juga menghadapi situasi sulit selama pandemi covid 19.

\section{UCAPAN TERIMA KASIH}

Ucapan terimakasih yang begitu besar kepada Tuhan YME karena dalam kondisi pandemi Covid 19 para dosen UKI tetap bisa melakukan kegiatan PKM dengan segala keterbatasan. Terimaksih yang begitu besar juga untuk Ketua FSBI yang memberikan kesempatan untuk kami masuk ke kawasan industri Pulogadung, para buruh perempuan yang bersedia memberikan waktunya untuk tim PKM melakukan kegiatan, dan kepada LPPM UKI yng memberikan ijin bagi kami melakukan kegiatan PKM.

\section{REFERENSI}

Fazraningtyas, W.A., Rahmayani, D., Fitriani, I.R. 2020. Kejadian Kekerasan Pada Perempuan Selama Masa Pandemi Covid-19. Dinamika Kesehatan: Jurnal Kebidanan dan Keperawatan. 11(1):362371. https://doi.org/10.33859/dksm.v11i1.550

Ismawati, I. 2019. Transformasi ibu rumah tangga menjadi buruh pabrik dalam meningkatkan ekonomi keluarga: Penelitian di Desa Galanggang Kecamatan Batujajar Kabupaten Bandung Barat. Skripsi. Bandung: Universitas Islam Negeri Sunan Gunung Djati.

Naan, N., Nurlaela, A. 2020. Struktur Insan sebagai Konsep Kepribadian Manusia Perspektif Sufi. Esoterik: Jurnal Akhlak dan Tasawuf. 6(2):217-234. http://dx.doi.org/10.21043/esoterik.v6i2.708 3

Pramanik, N.D. 2020. Dampak Bantuan Paket Sembako dan Bantuan Langsung Tunai terhadap Kelangsungan Hidup Masyarakat Padalarang pada Masa Pandemi Covid 19. Intelektiva: Jurnal Ekonomi, Sosial dan Humaniora. 1(12):113120.

Pujaningsih, N.N., Sucitawathi, I.G.A.A.G.D. 2020. Penerapan Kebijakan Pembatasan Kegiatan Masyarakat (PKM) Dalam Penanggulangan Wabah COVID-19 Di Kota Denpasar. Moderat: Jurnal Ilmiah Ilmu Pemerintahan. 6(3):458-470. http://dx.doi.org/10.25157/moderat.v6i3.35 37

Romlah, S. 2020. Covid-19 Dan Dampaknya Terhadap Buruh di Indonesia. 'Adalah: Jurnal Ilmu Hukum. 4(1):213-222. https://doi.org/10.15408/adalah.v4i1.16077

Sa'diyah, K., Amiruddin. 2020. Pentingnya Psychological Well Being di Masa Pandemi Covid-19. Kariman: Jurnal Pendidikan Keislaman. 8(2):221- 
232.

https://doi.org/10.52185/kariman.v8i02.149

Sari, N.A. 2015. Psychological Well-Being Pada Kepala Keluarga yang Mengalami Pemutusan Hubungan Kerja. Psikoborneo: Jurnal Ilmiah Psikologi. 3(2):213-223.

Setiati, S., Azwar, M.K. 2020. COVID-19 and Indonesia. Acta Medica Indonesiana. 52(1):84-89.

Timah, S. 2021. Hubungan Penyuluhan kesehatan dengan Pencegahan covid 19 di Kelurahan kleak kecamatan Malalayang Kota Manado. Indonesian Journal of Community Dedication (IJCD). 3(1):7-14.

Wakirin, W. 2017. Wanita Karir Dalam Perspektif Islam. Al-I'tibar: Jurnal Pendidikan Islam. 4(1):1-14. https://doi.org/10.30599/jpia.v4i1.148

Wijayanti, D.M. 2010. Belenggu Kemiskinan Buruh Perempuan Pabrik Rokok. Komunitas: International Journal of Indonesian Society and Culture. 2(2):84-93. https://doi.org/10.15294/komunitas.v2i2.22 78 